ISSN: 0213-2087 eISSN: 2444-7080

DOI: https://doi.org/10.14201/shhc2021394972

\title{
EL AFRICANISMO CASTRENSE: UN ESTADO DE LA CUESTIÓN
}

\section{The africanismo castrense: a bibliographical review}

\author{
Daniel MACÍAS FERNÁNDEZ \\ Universidad de Cantabria \\ https://orcid.org/0000-0001-7202-2653 \\ Sergio GARCÍA PUJADES \\ Universidad de Cantabria \\ https://orcid.org/0000-0003-3472-1271
}

Recibido: 01/03/2021 Revisado: 05/07/2021 Aceptado: 05/07/2021

RESUMEN: El propósito de este artículo es realizar un estado de la cuestión del africanismo castrense, un grupo militar forjado en el contexto colonial de las Campañas de Marruecos (1909-1927) y decisivo para comprender la historia contemporánea española del siglo xx. Para ello se ha procedido a una revisión sistemática de la bibliografía existente en torno al tema para estudiar su tratamiento a lo largo de los últimos años. De esta forma se pretenden desgranar las diferentes características que se atribuyen a estos militares para observar los puntos débiles de la situación actual de las investigaciones. A la par se propondrán algunas posibles vías de estudio y tratamiento del tema.

Palabras clave: Historia Militar; historiografía; siglo xx; campañas de Marruecos (1909-1927); Guerra del Rif.

ABSTRACT: The purpose of this article is to outline a state of the art about africanismo castrense, a Spanish military group forged in the colonial context of Moroccan Campaigns (1909-1927) and decisive for understanding Spanish contemporary history of the 20th century. To that end, a systematic review of existing bibliography has been made to study its treatment along recent years. In this way, the paper seeks to 
narrow down different characteristics that have been attributed to these soldiers in order to uncover current research weaknesses. At the same time, some possible ways forwards will be proposed. Rif War.

Key words: Military History; historiography; 20th century; Moroccan Campaigns;

\section{INTRODUCCIÓN}

La palabra africanismo induce a una polisemia en la historiografía española y, por ello, su acotación resulta muy compleja. Las opiniones sobre su significado son múltiples y muy variadas. Su sentido más amplio hace alusión a la corriente de pensamiento española que vertebraba a los sectores imperialistas: se puede decir que identificaba al partido colonial que abogaba por la expansión por África. Más allá de esta limitada definición el concepto se vuelve escurridizo, siendo variados los intereses, las formas, los protagonistas, las épocas, las intenciones, las justificaciones... Hay autores que defienden que tal movimiento nació a raíz del testamento de Isabel la Católica, de entre las filas de los que criticaron la conquista de América por ser una distracción de África, el supuesto verdadero destino de Castilla. Otros lo vinculan a la corriente capitalista moderna de las sociedades geográficas que veían en el colonialismo comercial -penetración pacífica- una forma de beneficiar al país por medio de la explotación de los recursos disponibles en el territorio colonizado. Las variantes entre ambas posturas son múltiples: Antonio Cánovas del Castillo y los conservadores abogaban por una intervención limitada, por el mantenimiento del status quo marroquí -no repartirlo entre metrópolis- y por influir en la región cultural y económicamente ${ }^{1}$. Los carlistas proponían una intervención con tintes evangélicos, a la manera del Manifest Destiny estadouniden$\mathrm{se}^{2}$. Por su parte, los militares españoles del siglo xx tenderían a buscar garantías estratégicas y prestigio internacional ${ }^{3}$.

1. En sus años de juventud el destacado político español abogaba por la intervención en Marruecos y llegó a escribir que «en el Atlas está nuestra frontera natural». En CánOvas del Castillo, Antonio: Apuntes para la Historia de Marruecos, Madrid: Victoriano Suárez, 1913, p. 276. En su madurez reculó de sus planteamientos iniciales sobre la cuestión y adoptó la postura dicha del status quo.

2. Muchas veces los discursos se hibridaban con tal de justificar la presencia de España en Marruecos. Un ejemplo de lo dicho, cual manual de tópicos del africanismo en tanto que partido colonial en ANónimo: Marruecos y España (Perfil de una obra), Madrid: Gráficas Casado, 1951. En su vertiente justificativa religiosa: "Parece que Dios, previendo la ceguedad de nuestros estadistas y políticos parlamentarios, se lo ha querido poner delante de los ojos para que supieran cuál era nuestra política internacional [...] hay un solo destino" (pp. 8-9).

3. Las distintas posturas citadas con respecto al africanismo se pueden encontrar en las siguientes obras: Anonimo: Marruecos y España..., pp. 7-36; Alonso, J. R.: Historia política del Ejército español, Madrid: Editora Nacional, 1974, p. 445; GuTierrez ConTreras, Francisco: «Notas sobre el africanismo a fines del XIX". Anuario de historia moderna y contemporánea, n. ${ }^{\circ} 4 / 5$, 1977-1978, pp. 325-346; BusQuETS, Julio.: El militar de carrera en España. Barcelona: Ariel, 1984, p. 101; Alonso BaQuer, M.: "El problema 
Retomando la definición de base, aquella que menciona el discurso procolonial africano, se ha de decir que fue la habitual en círculos intelectuales o con inquietudes culturales desde finales del siglo xIx; las tertulias políticas y empresariales también se prodigaron en tales lides, aunque eclosiona principalmente tras la pérdida de los últimos restos del viejo imperio español, previas guerras de independencia en Cuba (1895-1898) y Filipinas (1896-1898) y la guerra hispano-estadounidense de $1898^{4}$. Sin embargo, en este artículo vamos a analizar únicamente el africanismo castrense, es decir, al grupo militar que se conformó en el contexto de las Campañas de Marruecos (1909-1927) $)^{5}$ y entre cuyos representantes más conocidos estuvieron algunos de los responsables del golpe de Estado de 1936 contra la República. En este sentido, la Real Academia Española, al definir esta voz, incluye una acepción interesante con respecto al término de "africanista", a saber: "militar formado en campañas del norte de África, en el siglo xx" 6 .

Los africanistas tuvieron una destacada importancia en buena parte del siglo xx. Algunos autores ponen el acento en su participación en la guerra civil española y, a partir de tales hitos históricos, es cuando surgió el concepto «africanismo

de Marruecos». En Historia social de las Fuerzas Armadas españolas. La Restauración. Tomo V. Madrid: Alhambra, 1986, pp. 227-232; BACHOud, Andrée.: Los españoles ante las campañas de Marruecos. Madrid: Espasa Calpe, 1988; GIL Grimau, Rodolfo: “Corrientes ideológicas internas en el africanismo español». En Congreso internacional El Estrecho de Gibraltar, tomo III. Madrid: UnED, 1988, pp. 277-285; MAS CHAO, Andrés: La formación de la conciencia africanista en el Ejército español (1909-1926). Madrid: Talleres del Servicio Geográfico del Ejército, 1988 y "La formación de la conciencia africanista». En Congreso internacional El Estrecho de Gibraltar, tomo III, Madrid: unED, 1988, pp. 331-348; MoraLES LEZCANO, Víctor: Africanismo y orientalismo español en el siglo XIX. Madrid: UNED, 1988 y «El africanismo español del ochocientos (semblanza histórica y balance profesional)». En Congreso internacional El Estrecho de Gibraltar, tomo III, Madrid: UNED, 1988, pp. 287-308 y “El africanismo español: 1860-1975». En Les Elites Espagnoles a l'epoque contemporaine, Cahiers de l'Universite, 1982, pp. 157-173; Balfour, Sebastian y LA Porte, Pablo: "Spanish Military Cultures and the Moroccan Wars, 1909-1936». European History Quarterly, 30, 3, 2000, p. 312; BALfour, Sebastian: Abrazo mortal: De la guerra colonial a la guerra civil en España y Marruecos. Barcelona: Península, 2002 (2018), pp. 33-49, "España y las grandes potencias y los efectos del desastre de 1898". En BALFour, Sebastian y Preston, Paul: España y las grandes potencias en el siglo XX. Barcelona: Crítica, 2002, pp. 7-15; RAMIRO DE LA MATA, Javier: «España y el protectorado en Marruecos: aproximación a un proceso colonial». Anales de bistoria contemporánea, 23, 2007, pp. 296302 y Origen y dinámica del colonialismo español en Marruecos. Ceuta: Archivo Central de Ceuta, 2001, pp. 17-19; y Reguera Rodríguez, Antonio T.: "La formación de la conciencia africanista en España». En Diez Torre, A. R.: Ciencia y Memoria de África, actas de las III Jornadas sobre "expediciones científicas y africanismo español. 1898-1998". Madrid: Universidad de Alcalá, 2002, pp. 23-46.

4. Fue precisamente en estas guerras ultramarinas donde algunos autores fijan el «trauma» fundacional de los africanistas. Aunque pueda parecer contradictorio, en América o mejor dicho en la pérdida de las últimas viejas posesiones imperiales, es donde nace la vocación africana de parte del ejército español. En torno a la cuestión de la vinculación entre las guerras finiseculares y sus consecuencias y la formación de la conciencia africanista, véanse: "El militarismo español y la pesada herencia de la crisis finisecular» y "El regeneracionismo castrense», capítulos del libro de MACías Fernández, Daniel: Franco "nació en África»: los africanistas y las Campañas de Marruecos, Madrid: Tecnos, 2019.

5. Iglesias Amorín, Alfonso: "La cultura africanista en el Ejército español (1909-1975)», Pasado y Memoria. Revista de Historia Contemporánea, 15, 2016, p. 102

6. Consultado en https://dle.rae.es/africanista?m=form [consultado el 01/07/2021] 
franquista" o "africanismo de Estado" para designar el relato colonial oficial del régimen franquista hacia el Protectorado de Marruecos y la política exterior ${ }^{7}$. En el caso del presente trabajo nos centraremos exclusivamente en el análisis del africanismo castrense en su contexto de forja durante la fase inicial del Protectorado marroquí.

El africanismo, entendido como grupo militar, ha sido muy poco y también muy parcialmente estudiado hasta el momento. Que al estado del estudio sobre africanismo le corresponda este dictamen obedece, en gran medida, a que la cuestión ha sido objeto de un interés y un tratamiento similares a que los que hasta fechas muy recientes ha merecido en España el grueso de la historia militar: el olvido por parte de la Academia y un tratamiento corporativo por parte de las Fuerzas Armadas. La superación de tales preceptos clásicos es la que en los últimos tiempos está generando las claves para superar esa situación. Para ofrecer una visión lo más amplia y coherente posible es por lo que este apartado comienza con un repaso de la producción bibliográfica correspondiente a este género de la literatura histórica militar, así como de la evolución de los planteamientos y las metodologías seguidos por quienes lo han cultivado.

Para realizar el estado de la cuestión hemos llevado a cabo un análisis bibliográfico lo más exhaustivo posible dividiendo los estudios en torno al tema en dos vertientes. Por un lado, aquellos que entienden el africanismo como un estadio más dentro de la tradición intervencionista del Ejército español, con sus corporativismos e intereses contextuales; estos tienden a ser estudios de historia social y política de la institución militar y son los primeros en aparecer en la historiografía española, aunque en muchos casos no ofrecen una caracterización exacta del grupo estudiado. Y por otro, los trabajos que se han acercado a la cuestión ofreciendo principalmente interpretaciones de corte cultural. Por supuesto que en muchas autorías esta separación no es fácilmente reconocible, pero en general sí se pueden distinguir estudios con un corte más político y que tienden a tener un marco cronológico que supera las campañas de Marruecos, de los que se han centrado en el análisis de fuentes culturales a través de paradigmas antropológicos, de las mentalidades o de estudios de género, entre otros, y que, en este caso sí, se circunscriben de forma más exacta al contexto colonial inicial en el norte marroquí.

El trabajo se ha ordenado de la siguiente manera: en primer lugar se llevará a cabo un breve recorrido historiográfico centrado en la historia militar española y su acercamiento al concepto de africanismo. Posteriormente se procederá a realizar el análisis bibliográfico del concepto en las dos vertientes antes comentadas para, luego, llevar a cabo una síntesis de los debates en torno a los límites del concepto y su estudio. Por último, se propondrá una serie de ideas en torno a las nuevas posibilidades de análisis a modo de conclusión.

7. En torno a la cuestión del africanismo posterior a su fase de forja en las campañas de Marruecos, el estudio más completo al respecto es PARRA MonTSERRAT, David: La narrativa del africanismo franquista: génesis y prácticas socio-educativas. Tesis doctoral inédita, Universitat de València, 2012. 


\section{BREVE INTRODUCCIÓN HISTORIOGRÁFICA}

Como se ha adelantado, el grupo militar africanista no ha sido especialmente estudiado en la historiografía española hasta que en años recientes han surgido estudios específicos sobre el tema junto a otros análisis que, como se verá, han incorporado el concepto de formas variadas. Que el estudio del africanismo castrense, grupo militar decisivo para comprender el siglo xx español, haya tenido tan poco predicamento hasta fechas próximas se debe, seguramente, a la propia evolución de la historiografía española.

Si bien el estudio de aspectos militares históricos ha sido tradicionalmente prolífico, sobre todo en su desarrollo propiamente corporativo, una buena parte de la producción literaria se ha caracterizado por acercamientos positivistas y/o con sesgos ideológicos, o han sido escritos como mera justificación de hechos pasados. Esta tradición goza todavía de fuerza, especialmente en el ámbito editorial y de la divulgación histórica ${ }^{8}$, y por supuesto ha tratado el conflicto bélico colonial en Marruecos e, incluso, ha llegado a tocar el concepto de africanismo, siendo la obra del general Andrés Mas Chao un ejemplo de ello, sobre el que posteriormente se profundizará. Es ilustrativo de esta línea de investigación histórica, muy ligada al propio ámbito castrense, la Revista de Historia Militar, una veterana publicación (se lleva publicando desde 1957) que hasta hace bien poco ha sido la única referencia en la historiografía española para tales cuestiones.

Hay que esperar a los años sesenta del siglo xx para que lleguen los primeros estudios realizados por historiadores profesionales que se interesan en la historia militar 9 . Estos fueron escritos por hispanistas que pudieron consultar documentación que el franquismo negaba a investigadores nativos. Entre estos primeros estudios serios encontramos la obra de Stanley G. Payne Politics and the Military in Modern Spain (1967), obra imprescindible para la historia política de la milicia en España que en 1977 el propio autor completó con Ejército y sociedad en la España liberal (1808-1936) ${ }^{10}$. Otro trabajo relevante es el de Eric Christiansen, Los orígenes del poder militar en España. 1800-1854 (1974) ${ }^{11}$. Desde estos primeros estudios a caballo entre la historia militar y la historia política comienzan a florecer análisis realizados por historiadores españoles ${ }^{12}$ y así, a comienzos de los años setenta, el

8. Iglesias Amorín, Alfonso: "España y Marruecos: Guerra y colonialismo en los siglos XIX y XX». Revista Universitaria de Historia Militar, 8, 16, 2019, p. 12.

9. Uno de los estudios más exhaustivos en torno a la cuestión de la historiografía militar española y su evolución en Puell de la Villa, Fernando: "La historiografía militar en el tiempo presente». En RÉmOND, René (dir.): Hacer la Historia del siglo XX. Madrid: Biblioteca Nueva, pp. 147-170.

10. Ver Payne, Stanley G.: Los militares y la política en la España contemporánea. Francia: Ruedo Ibérico, 1976; y Ejército y sociedad en la España liberal, 1808-1936. Madrid: Akal, 1977.

11. Christiansen, Eric: Los origenes del poder militar en España. 1800-1854. Madrid: Aguilar, 1974.

12. Las publicaciones de Payne y Christiansen junto con la de BOYD, Carolyn P.: La política pretoriana en el reinado de Alfonso XIII. Madrid: Alianza, 1990 (publicada originalmente en inglés en 1979), publicadas en el contexto de los inicios de la democracia española, conformaron el núcleo central de 
general Alonso Baquer y el teniente general Manuel Díez-Alegría se adentraron en el estudio histórico del ejército español, donde el leitmotiv de la investigación era su vinculación con la política a través de lo que la crítica historiográfica académica ha definido como "pretorianismo" " ${ }^{3}$. En los años ochenta el historiador Carlos Seco Serrano mantuvo vivo el interés por esta cuestión con importante éxito ${ }^{14}$. De forma simultánea a lo dicho, se desarrolló una línea de investigación vinculada a la sociología militar, donde se ha de resaltar la obra del comandante Julio Busquets a finales de los años sesenta, auténtica precursora de este tipo de investigaciones en España ${ }^{15}$. No se puede dejar de citar las aportaciones de los politólogos Rafael Bañón y José Antonio Olmeda quienes, en los años ochenta, publicaron una compilación de textos de sociología aplicados a las Fuerzas Armadas procedentes de lo más granado del panorama sociológico internacional, lo que aportó una serie de conceptos y teorías procedentes, en muchos casos, de obras que no se encuentran traducidas al castellano y a los que se añaden artículos de los propios Bañón y Olmeda planteados a partir de algunas variantes militares españolas ${ }^{16}$.

Desde la llegada de estudios históricos que provenían de ámbitos universitarios y no de cuarteles, lo que coincidió en el tiempo con el final del franquismo, comenzaron a producirse investigaciones que manejaban claves de tipo cultural, investigaciones que tuvieron en el estudio de las mentalidades, un campo de enorme interés: Gabriel Cardona, Joaquín Lleixá o Fernando Puell de la Villa figuran

las obras clásicas de hispanistas cuyo tema central versa sobre la relación entre ejército y política. En cualquier caso, al tratar el tema de las familias militares y, en concreto, la africanista, los enunciados adquieren una forma muy difusa, en algunos casos anecdótica al tratar cuestiones muy concretas del africanismo; el propio interés de la investigación, un acercamiento macro a la política contemporánea española con el ingrediente militar, hacía que la consecuencia lógica fuese lo enunciado. En cualquier caso, el grupo africanista aparece y desaparece de la narración de esta historiografía clásica según sean o no relevantes para la política española del momento. Las familias militares no son estudiadas en sí mismas sino como herramienta explicativa de fenómenos más amplios y que son los que realmente interesaban: su apoyo al golpe de Primo de Rivera, su intervención en la desaparición de las Comisiones Informativas, el Informe Picasso y las convulsiones parlamentarias, su enfrentamiento con las Juntas de Defensa, etc.

13. Véase Alonso Baquer, M.: El ejército en la sociedad española. Madrid: Ediciones del Movimiento, 1971; y Díez-Alegría, M.: Ejército y sociedad. Madrid: Alianza, 1972. En las mismas coordenadas historiográficas se encuentra el monumental estudio de Alonso, J. R.: Historia política...

14. La gran aportación española a este tipo de estudios fue la ya aludida de SECo Serrano, Carlos: Militarismo y civilismo en la España contemporánea, Madrid: Instituto de Estudios Económicos, 1984. Ésta adolece de los mismos problemas enunciados para las obras de los hispanistas y, concretamente, trata las Campañas de Marruecos en escasas hojas sueltas, sin homogeneidad alguna y buscando únicamente explicar ciertos acontecimientos acaecidos en la política metropolitana.

15. Un buen compendio de sus estudios en BusQuETs, Julio: "La sociología militar en España». Revista de Estudios Políticos, 158, 1968. Asimismo son muy recomendables las lecturas: El militar de carrera en España, Barcelona: Ariel, 1984; y "Servicio militar: historia y problema». Historia 16, n. ${ }^{\circ} 225$, 1995.

16. Bañón, R. y Olmeda, J. A.: La institución militar en el Estado contemporánea, Madrid, 1985. 
entre algunos de los autores más destacados ${ }^{17}$. De esta forma, poco a poco, se va avanzando hacia una profesionalización del estudio y deja de ser una tarea realizada exclusivamente por los propios miembros del cuerpo militar, si bien es cierto que la vinculación de este tipo de estudios con las Fuerzas Armadas seguía siendo muy destacada. Muchos de los más brillantes historiadores eran militares e historiadores a la vez, siendo los casos de Cardona y de Puell de la Villa los más ilustrativos. En los años noventa, Manuel Espadas Burgos ya señalaba en el prólogo a la obra de Rafael Núñez Florencio Militarismo y antimilitarismo en España (18881906) que el estudio profesional de la historia militar se estaba normalizando en los departamentos universitarios ${ }^{18}$. Desde entonces su desarrollo está asentado con variadas líneas de investigación y prueba de ello es el surgimiento de revistas académicas especializadas en el área como, desde 2012, la Revista Universitaria de Historia Militar en lo que al ámbito científico se refiere, o las publicaciones divulgativas de calidad de la editorial Desperta Ferro, nacida en $2010^{19}$.

El anterior y breve recorrido por la historiografía militar en nuestro país es necesario para entender el tratamiento que han tenido las Campañas de Marruecos (1909-1927) dentro de aquella. La primera gran obra que cumplía con el rigor historiográfico data de los años setenta y es el estudio que el periodista David S. Woolman tituló: Abd el Krim y la guerra del Rif (1971), donde, además de una narración coherente y completa de las guerras norteafricanas, se utilizan conceptos antropológicos tomados de los análisis del estadounidense David Hart, quien como con su mujer Úrsula Kingsmill Hart realizó importantes estudios sobre

17. CARDONA, Gabriel: El poder militar en la España contemporánea hasta la guerra civil, Madrid: Siglo xxi, 1983; Lleixà, Joaquim: Cien años de militarismo en España. Funciones estatales confiadas al ejército en la Restauración y el franquismo, Barcelona: Anagrama, 1986; Puell DE LA VilLA, F.: El soldado desconocido: de la leva a la "mili" (1700-1912), Madrid: Biblioteca Nueva, 1996. En la misma línea de nuevos estudios de lo militar destacamos a Ballbé, Manuel: Orden público y militarismo en la España constitucional (1812-1983). Madrid: Alianza, 1983 y Gonź́LEZ CALLEjA, E.: La razón de la fuerza. Orden público, subversión y violencia política en la España de la restauración (1875-1917). Madrid: CSIC, 1998; y El máuser y el sufragio. Orden público, subversión y violencia política en la crisis de la Restauración (1917-1931). Madrid: CSIC, 1999.

18. Espadas Burgos, Manuel: «Prólogo», en Nuñez Florencio, Rafael: Militarismo y antimilitarismo en España (1888-1906), Madrid: CSIC, 1990. En el mismo sentido hay que citar la obra del profesor Carlos Navajas Zubeldía Ejército, estado y sociedad en España (1923-1930). Logroño: Instituto de Estudios Riojanos, 1992.

19. Hasta el momento la Revista Universitaria de Historia Militar ha publicado un monográfico dedicado a las Campañas de Marruecos (vol. 8, n. ${ }^{\circ}$ 16, 2019) y otro a las guerras coloniales españolas en época contemporánea (vol. 2, n. ${ }^{\circ} 3$, 2013). Desperta Ferro ha publicado un número sobre Annual (n. ${ }^{\circ}$ 30) y otro sobre el desembarco de Alhucemas (n. ${ }^{\circ} 11$ ). Esta misma editorial ha editado un libro con motivo del centenario de Annual que consta de once capítulos donde algunos de los principales especialistas en la cuestión de las Campañas de Marruecos, en la historia política o en las relaciones internacionales del periodo, ofrecen una completa y renovada visión sobre la debacle militar de 1921, sus antecedentes, sus consecuencias y aspectos poco conocidos del contexto bélico donde acaeció. Macías Fernández, Daniel (ed.): A cien años de Annual. La guerra de Marruecos. Madrid: Desperta Ferro, 2021. 
antropología de los bereberes marroquíes ${ }^{20}$. Le siguieron estudios como los del historiador Shannon E. Fleming ${ }^{21}$ o el estudio de la historiadora Andrée Bachoud sobre el impacto de Marruecos para los distintos colectivos españoles ${ }^{22}$. A partir de los años noventa comenzó a publicarse un mayor volumen de investigaciones, entre las que se pueden destacar las monografías de María Rosa de Madariaga ${ }^{23}$ y la obra sobre el tema rifeño del también historiador Richard C. Pennell ${ }^{24}$. Destacan además las investigaciones que han analizado las campañas de Marruecos para explicar el golpe de Estado de julio de 1936 y la guerra civil española, sobresaliendo la obra de Sebastian Balfour Abrazo mortal. De la guerra colonial a la Guerra Civil en España y Marruecos (1909-1939). Esta es la principal muestra de toda una serie de investigaciones que tienen su centro neurálgico y el cuartel general de sus investigadores en la Cañada Blanch Centre de la London School of Economics and Political Science (Londres), dirigido por el hispanista Paul Preston, cuyos estudios han evidenciado la relación de causalidad entre la guerra colonial en el Protectorado de Marruecos y la guerra civil ${ }^{25}$, insistiendo en el peso de los africanistas en el desarrollo del golpe de Estado de 1936. Esta tesis, que relaciona la guerra colonial y el posterior conflicto bélico fratricida, resulta verosímil y ha generado una línea de estudio que analiza la utilización de tropas coloniales y marroquíes en la revolución de Asturias (1934) y en la guerra civil, y que está sirviendo como marco de

20. Algunas referencias básicas de David y Úrsula Hart: HART, David: Estructuras tribales precoloniales en Marruecos bereber, 1860-1933: una reconstrucción etnográfica en perspectiva histórica. Granada: Universidad de Granada, 1997; KIngSmil HaRT, Úrsula: Tras la puerta del patio, la vida cotidiana de las mujeres rifeñas. Melilla: Biblioteca de Melilla, 2006.

21. Tesis doctoral que entra a la perfección en los cánones de una investigación concienzuda de historia militar clásica. Ver Fleming, S. E.: Primo de Rivera and Abd el Krim: The struggle in Spanish Morocco, 1923-1927. Madison: Universidad de Wisconsin, 1974. 1988.

22. Bachoud, Andrée: Los españoles ante las campañas de Marruecos. Madrid: Espasa Calpe,

23. Destacamos Madariaga, María Rosa: «Imagen del moro en la memoria colectiva del pueblo español y retorno del moro en la Guerra Civil de 1936». Revista Internacional de Sociología, 4, 1988; España y el Rif. Crónica de una historia casi olvidada. Málaga: La Biblioteca de Melilla, 1999; "El Protectorado Español en Marruecos: algunos rasgos distintivos y su proyección en el presente». Anales de Historia Contemporánea, 23, 2007; "Los estudios sobre el Protectorado español en perspectiva». En: López García, Bernabé y Hernando de larramendi martínez, Miguel (coords.): Historia y memoria de las relaciones hispano-marroquies. Un balance en el cincuentenario de la independencia de Marruecos. Ediciones del Oriente y del Mediterráneo, 2007, pp. 21-44 y Abd el-Krim el Jatabi. La lucha por la independencia, Madrid: Alianza, 2009.

24. Pennell, C. Richard: La Guerra del Rif: Abd-el-Krim el Jattabi y su Estado rifeño. Melilla: UNED y Consejería Cultural de la Ciudad Autónoma de Melilla, 2001. Aunque la fecha de publicación es relativamente reciente, el trabajo de Pennell sobre el tema rifeño se retrotrae a su época de doctorando en los años ochenta en la Universidad de Leeds. Un artículo de ese periodo que viene a compendiar buena parte de sus reflexiones en Pennell, C. Richard: «Éxito y fracaso de Abd el Krim». Historia 16, 126, 1986.

25. La Porte, Pablo: "Civil-Military Relations in the Spanish Protectorate in Morocco: The Road to the Spanish Civil War, 1912-1936”. Armed Forces E Society, 30, 2, 2004. 
análisis para proponer una explicación de la desmedida y brutal violencia militar contra los civiles en los mencionados conflictos ${ }^{26}$.

Sin embargo, en estos estudios no hay un análisis definido del concepto de africanismo castrense más allá de citar a un colectivo militar que se forja en el contexto colonial, donde la brutalidad, la separación del mundo civil, el militarismo, el imperialismo, la masculinidad y el espíritu del sacrificio adquieren una importancia sin parangón en el contexto de la España del primer tercio del siglo xx. Este problema de definición lleva a que, posiblemente, el concepto de africanismo se haya explicado mediante la imagen de esos mandos que se hacen con los aparatos del Estado tras la guerra civil. A través de estos militares, siendo Francisco Franco la cabeza más visible y reconocida de todos ellos, se deduce el concepto de africanismo en época de las Campañas de Marruecos, es decir, se cae en un anacronismo.

A pesar de este interés historiográfico y la proliferación de trabajos en las últimas décadas, el concepto de africanismo no ha sido especialmente tratado, al menos hasta fechas todavía muy recientes, lo cual no significa que no existan trabajos al respecto. Ya hemos avisado de que la primera obra que hace un tratamiento explícito del africanismo es la monografía del militar Andrés Mas Chao, $L a$ formación de la conciencia africanista en el Ejército español (1909-1926) (1988) ${ }^{27}$. Por su parte, el historiador estadounidense Geoffrey Jensen llevó a cabo diferentes estudios en los años noventa con el fin de comprender las bases ideológicas y culturales del africanismo, aunque no abordó de forma específica el tema ${ }^{28}$.

Actualmente, a pesar de haber un buen volumen de obras en castellano tratando la cuestión de las Campañas de Marruecos y, con ellas, de los africanistas, estos no dejan de ser un mero término sin desarrollar en el grueso de las primeras ${ }^{29}$. Aun cuando se trabaja el concepto, no existe un consenso a la hora de definir su significado más allá de ciertos tópicos ampliamente aceptados que, aunque

26. Véase para esta cuestión el reciente trabajo de Pablo SÁnchez LEón, donde utiliza esta relación causal entre guerra colonial y guerra civil: Exterminables sin deliberación. Cómo estudiar las masacres de civiles en la destrucción de la república democrática española. Madrid: Postmetrópolis, 2020. Entre otros trabajos que siguen la línea de investigación iniciada por Balfour debe citarse el de Nerín, Gustau.: La guerra que vino de África. Barcelona: Crítica, 2005.

27. En el mismo año de publicación del libro, 1988, publicó el artículo «La formación de la conciencia africanista». En Congreso internacional El Estrecho de Gibraltar, tomo III. Madrid: UNED, 1988, pp. 331-348, en el que resumen partes de la obra citada, sin ninguna innovación.

28. Ver Jensen, Geoffrey: Intellectual foundations of Dictatorship: Spanish military writers and their quest for cultural Regeneration. New Haven: Universidad de Yale, 1995.

29. Sirva de ejemplo una de las últimas publicaciones sobre las Campañas de Marruecos (2021), la ya citada A cien años de Annual de Daniel Macías (ed.), donde se encuentran más de cincuenta veces nombrado el término "africanista", a las que hay que añadir otra decena de "africanismo». Este libro coral con algunos de los más reconocidos especialistas sobre la cuestión citan tales términos sin grandes explicaciones, aunque no es el leitmotiv de la publicación. Hay una gran diversidad en los matices conceptuales que usan los catorce autores. Fernando Puell y José Vicente Herrero son los únicos que hacen un mínimo esbozo de definición: «un grupo relativamente limitado de cuadros de mando, que servían, sobre todo, en las unidades indígenas» (p. 50). 
puedan funcionar bien para definir a la ligera diferentes sectores del Ejército español entre los años veinte y treinta del siglo xx, presentan problemas en el momento en el que se desciende a la complejidad de la realidad de la época. Podemos resumir diciendo que ha tendido a darse una aproximación generalista al fenómeno del africanismo militar y que en los últimos años un buen número de estudios de distintas facetas del Protectorado y de sus moradores, permanentes o temporales, están permitiendo conocer mucho mejor la realidad militar en Marruecos y, por esto mismo, esa definición generalista de africanismo castrense ya no nos encaja tan bien en el puzle colonial.

\section{Historia POLÍTICA Y AFRICANISMO}

El africanismo castrense se forjó en las Campañas de Marruecos y muchos de sus actores tuvieron una trayectoria decisiva en episodios políticos posteriores, entre los que destacan los acaecidos en el periodo de la II República, en el golpe de Estado del 18 de julio de 1936, la guerra civil española y la siguiente dictadura del general Francisco Franco, algo ya mencionado con anterioridad. Esta importante participación en la política española del siglo xx significa que estos militares continúan la estela lejana que fue dejando el Ejército a lo largo de la historia contemporánea de España. La intervención de la institución castrense en la vida política nacional se puede rastrear desde inicios del siglo xIx. En este sentido el general Francisco Javier de Elío y su ofrecimiento a Fernando VII para subvertir el orden constitucional en 1814 puede ser entendido como el primero, y ha dado lugar a multitud de análisis de cómo las Fuerzas Armadas en su conjunto o, más frecuentemente en el siglo XIX, individuos destacados procedentes de las mismas intervienen en la vida civil ${ }^{30}$. Siguiendo lo anterior, la familia africanista tendrá su lugar en este tipo de estudios: tiende a caracterizarse por su corporativismo y por presionar, de forma directa o indirecta, a los poderes civiles. El ejemplo más claro es su defensa enconada de la expansión manu militari por el norte de África y su radical oposición a las Juntas de Defensa y a todos los que se resistieran a los ascensos por méritos de guerra, lo que acabaría por generar serios problemas a los gobiernos españoles de la época.

Esta tendencia al intervencionismo en la vida pública por sectores del ejército se vigorizó a partir de la crisis finisecular española (1898) y en los primeros compases del siglo xx, donde el denominado regeneracionismo tuvo su propia vertiente militar.

30. La expresión «Era de los Pronunciamientos» es un clásico en la terminología de este periodo histórico al hablar de política española, así como el concepto «espadón», el militar de alta graduación que tomaba el poder por la fuerza para un sector político nacional. Para tener una idea general de la situación político militar de la España Contemporánea, son referencias obligatorias: AlONSO, J. R.: Historia política...; PAYne, Stanley G.: Ejército y sociedad en la España liberal...; CARdona, Gabriel: El poder militar en la España contemporánea hasta la guerra civil. Madrid: Siglo XXI, 1983; SECO SERRANO, Carlos: Militarismo y civilismo en la España contemporánea...; y Puell DE LA VILlA, Fernando: Historia del Ejército en España. Madrid: Alianza, 2005. 
Fruto de lo dicho, toma fuerza el concepto de militarismo, un ingrediente esencial del ejército español del periodo y de buena parte del siglo xx. La primera obra canónica que abordó el intervencionismo militar en la historia española fue la de Payne, Politics and the Military in Modern Spain, ya mencionada anteriormente ${ }^{31}$.

Siguiendo algunos de los análisis clásicos de las obras interesadas en el militarismo español, el africanismo castrense retomaría la costumbre de intervención política tan repetitiva en la historia contemporánea de España, si bien no suele ser una familia bien definida en este tipo de estudios. Incluso los últimos trabajos sobre la cuestión siguen la misma línea de cierta indefinición. Por ejemplo, la novísima obra del historiador Juan Carlos Losada El ogro patriótico (2020), de carácter divulgativo, explica la importancia de la guerra colonial a la hora de forjar un tipo concreto de mentalidad en los militares, pero no ofrece una definición específica de aquellos. El profesor Francisco Alía Miranda publicó dos años antes que Losada otra obra con intereses historiográficos similares: Historia del ejército español y de su intervención en política (2018). En su repaso del militarismo patrio tampoco realiza ninguna concreción sobre el africanismo ${ }^{32}$. Por otro lado, la obra de Carlos Arenas Posadas, Por el bien de la patria (2019), que tiene un marco cronológico muy ambicioso puesto que revisa el corporativismo en la historia militar desde la Baja Edad Media, especifica que el africanismo es un militarismo concreto con valores protofascistas relevantes, entre los que se puede resaltar un exacerbado darwinismo social ${ }^{33}$. Además, al igual que Losada o Alía, contrapone el africanismo

31. Ver Payne, Stanley G.: Los militares y la política... y Ejército y sociedad... En este sentido, otras destacadas obras en esta línea de estudios: Lleixà, J.: Cien años de militarismo en España. Funciones estatales confiadas al ejército en la Restauración y el franquismo. Barcelona: Anagrama, 1986; Blanco Escolá, Carlos: La Academia General Militar de Zaragoza (1928-1931). Barcelona: Labor, 1989; Nuñez Florencio, R.: Militarismo y antimilitarismo en España (1888-1906). Madrid: csic, 1990 o BoYD, Carolyn P.: La política pretoriana en el reinado de Alfonso XIII. Madrid: Alianza, 1990. Una obra nacional del periodo franquista con cierto interés y anterior a los clásicos de los hispanistas es la de Melchor Fernández de Almagro: Historia política de la España Contemporánea, Madrid: Alianza, 1956.

32. Se quiere destacar que ambos autores son excelentes investigadores en el campo de la historia militar y, a pesar de esta demostrada solvencia, no definieron un término que, a la vista de lo que se está mostrando, es escurridizo en su caracterización. Ver Losada, Juan Carlos: El ogro patriótico. Los militares contra el pueblo en la España del siglo Xx. Pasado \& Presente: Barcelona, 2020. Alía Miranda, Francisco: Historia del ejército español y de su intervención en política. Del desastre del 98 a la Transición. Los libros de la Catarata: Madrid, 2018. Un último trabajo sobre el intervencionismo militar es el de Roberto Muñoz Bolaños que establece una perspectiva comparada entre España, Reino Unido y EE. uU., centrándose en la Restauración aunque sin estudiar el caso africanista: MuÑoz Bolaños, Roberto: "Are we so Different? Military Interventionism in Spain, the United Kingdom and the United States». Araucaria. Revista Iberoamericana de Filosofía, Política, Humanidades y Relaciones Internacionales, año 23, 47, 2021, en prensa.

33. Los autores del presente artículo entienden que el darwinismo social y el racismo son características a tener en cuenta a la hora de analizar la mentalidad del africanismo castrense. La demostración más completa de lo dicho está en la tesis doctoral de JENsEn, Geoffrey: Intellectual foundations of Dictatorship... Especialmente interesante para esta cuestión es el caso analizado del irracionalismo del general Burguete. Para profundizar en cómo estas convicciones eran demostradas por los africanistas castrenses más insignes, véase Velasco de CASTRO, Rocío: "La imagen del "moro» en la formulación e 
al fenómeno de las Juntas de Defensa ${ }^{34}$. En cualquier caso, en estas obras lo que define al africanismo castrense es la continuidad de la intervención armada en la política y la característica evidente de su génesis colonial en el norte de África.

En su ya citado estudio, Mas Chao es el primero que se atreve a ofrecer una caracterización concreta de la génesis colonial del africanismo castrense, en un momento tan temprano como los años ochenta. El problema reside en que el autor atribuye la misma identidad a todos los miembros del Ejército que sirvieron en las colonias españolas en África, sin distinguir entre los que lo hicieron en el Sahara, en el Protectorado Sur de Marruecos o en el Protectorado Norte. De esta forma se obvian las diferencias que hubo entre todos esos territorios y entre los procesos y fenómenos ocurridos en los mismos. Además, el hecho de que el autor identifique a todos los militares que sirvieron en las colonias "musulmanas" como africanistas no se corresponde con la compleja realidad del ejército español en África. De hecho, como veremos, si se estudia un área mucho más homogénea como fue el Protectorado Norte de Marruecos, donde se conformó el grupo africanista, se observa que convivieron diferentes familias militares. Además, su obra, que hay que situar, siguiendo el repaso bibliográfico anterior, entre la historiografía procedente del seno de las Fuerzas Armadas, ofrece juicios de valor que no son fácilmente asumibles por la crítica académica. Es significativa la siguiente cita como ejemplo de las valoraciones del autor; referente al ejército y al selecto grupo colonial:

aún sigue atesorando profundas virtudes militares, especialmente en una minoría que se siente asfixiada por el mediocre entorno profesional en que viven, para quienes la campaña marroquí supuso el encuentro de una nueva ilusión ${ }^{35}$.

Así, comparando los militares burócratas de la Península con los africanistas, afirmó:

frente a esta mayoría [burocrática], un pequeño grupo de entusiastas, pletórico de espíritu, mantiene una entrega constante al servicio, renovado y apoyado por la joven oficialidad que sale de las Academias con un alto espíritu militar y buena formación teórica ${ }^{36}$.

Ocupándose de Annual, posiblemente un catalizador del fenómeno africanista, Mas Chao escribió acerca de los legionarios que «demostraron una vez más con sus bajas y heroísmo que las recompensas las ganaban no por favoritismo, sino por claros merecimientos» y finalizó su relato de las actuaciones más destacadas

instrumentalización del africanismo franquista». Hispania. Revista española de Historia, vol. XXLIV, 256 , 2014, pp. 205-236.

34. Arenas Posadas, Carlos: Por el bien de la patria. Guerras y ejércitos en la construcción de España. Barcelona: Pasado \& Presente, 2019, pp. 203-204.

35. Mas Chaо, Andrés: La formación de la conciencia africanista en el Ejército español (19091926). Madrid: Talleres del Servicio Geográfico del Ejército, 1988, p. 49.

36. Ibid., p. 20 
con una laudatoria a las tropas de choque que allí sirvieron, que en su opinión "ennoblecieron con su sangre y ejemplo" a España ${ }^{37}$. Se insiste en este autor y sus tesis porque, hasta tiempos recientísimos, fue el único que trató de estudiar a los africanistas y, como mínimo, entendió que eran un grupo homogéneo con ciertas características compartidas. En el caso de Mas Chao, se pone el acento en las virtudes del "heroico infante» cual seña de identidad del africanismo.

En cualquier caso, el africanismo como familia militar no puede desligarse de los numerosos corporativismos habituales en el Ejército español que comenzaron a expresarse a través de oposiciones entre Armas y Cuerpos, las ramas tácticas (Infantería y Caballería) enfrentadas a las técnicas (Artillería, Ingenieros y Sanidad) y, generalmente, todos ellos contra los de Estado Mayor. El peso de la rivalidad corporativa no es exclusivo del Ejército español, pero seguramente, como evidencia el historiador José Vicente Herrero Pérez, generó serios problemas en la efectividad combativa de la institución armada ${ }^{38}$. Esta tradición corporativista, rastreada desde el siglo XIX, sigue vigente durante los conflictos coloniales de inicios de siglo xx y llevó a la oficialidad africanista a defender una muy clara postura en torno a la promoción por méritos de guerra, estando rotundamente a favor. Por eso mismo se ha entendido a los militares africanistas como la cara opuesta del fenómeno de las Juntas de Defensa, partidarias del ascenso por riguroso orden en el escalafón. Tal antagonismo entre grupos castrenses se aireó en los medios de comunicación, en donde diferentes sectores políticos apoyaron las reivindicaciones de una u otra facción militar ${ }^{39}$. Sin embargo, esta distinción corporativista entre junteros y africanistas no funciona para todos los casos ya que, como señala el hispanista Sebastian Balfour, José Riquelme, que era presidente de la Junta de Infantería de Melilla, puede ser considerado a la par africanista y juntero. Esta aparente naturaleza imposible se explicaría insertando un adjetivo al primer concepto: africanista "progresista" ${ }^{40}$. Este detalle terminológico tiene un profundo calado, pues si existe una corriente "progresista" es porque adivinamos que hay también otra "conservadora». Más aún, se está dando una subdivisión de corte político a la familia militar que se está tratando. Más allá de la consistencia de tal realidad, lo cierto e indiscutible es que los africanistas tenían variadas posiciones ideológicas en el plano político. Una forma alternativa de tratar la cuestión de las distintas sensibilidades políticas o, incluso, particularidades específicas dentro del grupo general es

37. Ibid., p. 55 .

38. Herrero Pérez, José Vicente: The Spanish Military and Warfare from 1899 to the Civil War. The uncertain path to Victory. London: London: Palgrave MacMillan, 2017, pp. 36-59.

39. Balfour, Sebastian y La Porte, Pablo: «Spanish Military Cultures...», p. 309; Macías Fernández, Daniel: "Franco nació en África»..., pp. 422-423; Alía Miranda, p. 39; García Álvarez-Coque, Arturo: Los militares de Estado Mayor en la Guerra Civil Española (1936-1939). Tesis doctoral inédita, Universidad Complutense, 2018, aplica el concepto de africanista a aquellos oficiales que logran ascensos rápidos por méritos de guerra, pp. 77, 94. Existe una versión publicada de esta tesis doctoral realizada por la editorial Comares (Granada) en 2018 con el título La fractura del Ejército ante el 18 de julio.

40. Balfour, Sebastian: Abrazo mortal..., pp. 267-268; Iglesias Amorín, Alfonso, "La cultura africanista...", p. 101. 
a través de la propia edad de los miembros. Algunas investigaciones distinguen dos generaciones de militares africanistas, los «viejos» y los «jóvenes» ${ }^{41}$. El general Alonso Baquer es probablemente quien mejor y más concienzudamente desarrolla esta idea que, en base a esta investigación, se resume en que la "generación del 98", aquella que se benefició de los méritos de guerra en el contexto de los conflictos de finales del siglo xIx, y la "generación del 23", la cual hizo lo propio con las Campañas de Marruecos (especialmente entre 1917 y 1923) se corresponderían con los africanistas sénior y los júnior respectivamente ${ }^{42}$. Aunque es muy difícil encajar a todos en grupos estancos, ya sean generacionales o de corrientes políticas, lo cierto es que más allá de las dinámicas propias de la edad había unos sustratos ideológicos comunes en la familia africanista, muchos de cuyos puntos centrales provenían de su propio desarrollo profesional: el modelo heroico de soldado ${ }^{43}$.

Hay otras opciones a la hora de subdividir a los africanistas. Así, muchas veces parecen surgir de la búsqueda de una explicación anacrónica para averiguar el motivo tras el bando elegido en la guerra civil española. María Rosa de Madariaga habla del "africanomilitarismo" para diferenciarlo del discurso colonial africanista de origen decimonónico, que también estaba presente entre algunos militares destinados en el Protectorado. En el fondo, la distinción de Madariaga es entre partidarios de la mano dura y los pactistas ${ }^{44}$. Por su parte Balfour y Pablo La Porte distinguen, dentro del seno del africanismo castrense, a los que denominaron "civilistas", aquellos que tenían puestos en la Alta Comisaría y en la administración general del Protectorado (como el caso de los interventores), mucho más respetuosos con las tradiciones locales debido a su labor de establecimiento y control colonial; y los "militaristas", los integrantes de los cuerpos de choque y unidades de vanguardia o extrema retaguardia (las más fogueadas en el conflicto norteafricano) ${ }^{45}$. En el

41. Balfour, Sebastian, Abrazo mortal..., pp. 257 y ss.

42. Alonso Baquer, M.: "La selección de la élite militar española». En Historia social de las Fuerzas Armadas españolas. La Restauración. Tomo V. Madrid: Alhambra, 1986, pp. 29-80.

43. Las generaciones militares de tipo heroico del 98 y del 23, según la terminología de Alonso Baquer, convivieron en el escenario de las campañas de Marruecos, al menos, en los primeros años del mismo. El caso paradigmático de lo dicho es el del general José Marina. Este fue considerado por los africanistas como el iniciador de la tarea imperial de España en África. Por lo dicho, fue uno de los referentes iniciáticos del africanismo.

44. Madariaga, María Rosa de: Los moros que trajo Franco. La intervención de tropas coloniales en la Guerra Civil Española. Barcelona: Martínez Roca, 2002, p. 44.

45. Balfour, Sebastian y La PorTe, Pablo: «Spanish Military Cultures...», pp. 317 y 319 . Dentro del primer grupo estarían los oficiales interventores, los arabistas españoles. El caso más destacado de militar interesado por la cultura, la lengua y las costumbres de los nativos fue el coronel Blanco de Izaga. Un buen análisis para entrar en contacto con el autor y su obra en Blanco, E.; Bravo Nieto, A.; Moga Romero, V. y HART, D.: Blanco de Izaga, coronel en el Rif: una selección de su obra, publicada e inédita, sobre la estructura sociopolítica de los rifeños del norte de Marruecos. Melilla, Ayuntamiento de Melilla, 1995. El grupo de los interventores, puesto dual pues podía ser llevado a cabo tanto por civiles como por militares, ha sido estudiado por José Luis ViLlanova y entre sus trabajos destacamos: "La academia de interventores del Protectorado de España en Marruecos». Aldaba: revista del Centro Asociado a la UNED en Melilla, 31, 2001, pp. 385-404; "La pugna entre militares y civiles por el control de la actividad 
caso de las divisiones enunciadas, las supuestas ramas dentro del tronco africanista se diferenciarían principalmente en el tipo de estrategia que seguir para pacificar el territorio asignado por los acuerdos internacionales. A saber: la expeditiva, que conllevaba la inversión decidida de los gobiernos de Madrid en hombres y recursos bélicos para acometer con garantías una rápida conquista militar en la que la sumisión y el desarme eran claves; y la opción política, que contemplaba el acercamiento a las cabilas más proclives a la causa española y aceptaba los tratos como un mal menor en la expansión. En cualquier caso, estos matices en la estrategia que seguir no influían en la existencia de un grupo auto reconocido y cohesionado en el territorio administrado desde Tetuán. La mencionada cohesión grupal se hizo patente con el Desastre de Annual. El año de 1921 y el descalabro militar en la Comandancia de Melilla hicieron que los africanistas, independientemente de las sensibilidades particulares, se convirtiesen en un puño cerrado dispuesto a golpear al traidor marroquí ${ }^{46}$. En el mismo sentido, la clara oposición a la estrategia de repliegue del general Miguel Primo de Rivera a la famosa Línea Estella fue otro de sus aglutinantes ${ }^{47}$. La hostilidad al dictador tuvo su expresión más famosa en el conocido desplante, más o menos mitificado, de Ben Tieb en 1924. El sector africanista mostró ampliamente su descontento ante la estrategia de semiabandono de Primo de Rivera y, aunque se ha dado quizá un excesivo protagonismo intimidatorio a los africanistas en tal campamento, la oposición influyó en el directorio militar y en el curso de las siguientes operaciones, que pasaron a ser ofensivas ${ }^{48}$.

\section{El AFricANismo DESDE LOS ESTUdios CUltURALES}

Recientemente se han ido publicando trabajos de diverso tipo que ofrecen un tratamiento del africanismo o de su área y tiempo de forja a partir del ámbito de la historia cultural, acercando el estudio hacia campos como la sexualidad, el

interventora en el protectorado español en Marruecos (1912-1956)». Hispania: Revista española de Historia, vol. 65, 220, 2005, pp. 683-716; "Los interventores del Protectorado español en Marruecos (1912-1956) como agentes geopolíticos». Ería: Revista cuatrimestral de geografía, 66, 2005, pp. 93-111.

46. Incluso la opinión pública española, muy poco proclive a la guerra e, incluso, a la propia institución armada, se lanzó a pedir venganza y medidas contundentes contra los que habían sesgado la vida de miles de españoles en el verano de 1921. Una buena síntesis de lo enunciado en GAJATE BAJO, María: "El fenómeno "Rally round the flag» y las campañas españolas en Marruecos de 1909 y 1921». En: Gomez OchoA, Fidel Ángel. et al.: La Guerra: Retórica y propaganda (1860-1970). Madrid: Biblioteca Nueva, 2014.

47. En el comienzo de la dictadura de Primo de Rivera, las Juntas de Defensa perdieron fuelle y el conflicto entre estas y los africanistas ya no servía de pegamento grupal tanto como en otros momentos pasados (el corporativismo en pos de los méritos de guerra). Por ello, la oposición en torno a la estrategia de abandono del Protectorado -más o menos acusada- fue un nuevo aglutinante grupal. Véase Herrero Pérez, José Vicente: The Spanish Military... p. 144; Atienza Peñarrocha, Antonio: Africanistas y junteros... p. 270.

48. Macías Fernández, Daniel: Franco..., pp. 391-405; Atienza Peñarrocha, Antonio: Africanistas y junteros..., pp. 502-508. 
cuerpo, la alimentación, etc. Como afirma Cristina Borreguero Beltrán, esta penetración de la historia cultural en el campo militar ha sido fructífera al introducir una interdisciplinariedad que ha permitido, entre diferentes cuestiones, un análisis de las identidades militares ${ }^{49}$. En el caso que nos ocupa, estas aproximaciones se han centrado en la vida cotidiana del soldado, en su producción literaria/periodística o, desde los estudios de género, en la construcción de una masculinidad bélica.

Distintos autores señalan que los africanistas eran reconocidos en la época porque solían aparecer frecuentemente en medios de comunicación del periodo, tales como la prensa o el cine, o porque generaban sus propios aparatos mediáticos (la Revista de Tropas Coloniales, a partir de su fundación en 1924, es el más significativo de todos). Tales acciones servían para dotarse de un aparato generador de filias a través de la propaganda, al mismo tiempo que ayudaban a reforzar el espíritu gru$\mathrm{pal}^{50}$. Este grupo de africanistas era sumamente consciente de su promoción en los medios de comunicación, y solía mostrar peculiares gustos orientalistas delante de la prensa al lucir prendas indígenas como djeballas, mostrar preocupación por conocer las costumbres locales y/o al presumir de hablar árabe, aunque esto último podía reducirse a pronunciar tantas palabras como dedos hay en la mano. Otra característica que aparece en la bibliografía más novedosa sobre la cuestión del africanismo es el culto a las cicatrices como testimonios del furor del combate, proporcionando y promocionando un aura romántica en torno a estos oficiales. Ello está ligado al modelo profesional por el que se inclinaban: el heroico, contrario al técnico ${ }^{51}$. Es evidente que no se puede extender a todo el africanismo la veneración por la herida de guerra; sin embargo, los principales exponentes del grupo, con fama y popularidad indiscutibles, se enorgullecerían de sus remiendos. Los medios de comunicación del periodo o los propios de la facción africanista se encargaron de difundir con profusión los sacrificios físicos de una serie de oficiales icónicos: José Sanjurjo, José

49. Borreguero Beltrán, Cristina: «La historia militar en el contexto de las nuevas corrientes historiográficas: una aproximación". Manuscrits: Revista d'historia moderna, 34, 2016, pp. 160-161.

50. Atienza Peñarrocha, Antonio: Africanistas y junteros... pp. 274-275; Marín Molina, Cristóbal: "La película La Malcasada como ejemplo de la proyección de la imagen estereotipada de los militares africanistas en los medios de comunicación». Revista Universitaria de Historia Militar, 6, 11, 2017, pp. 217-238. Una interesante aportación sobre los escritos africanistas en MogA Romero, Vicente: La cuestión marroqui en la escritura africanista. Barcelona: Bellaterra, 2008. El autor define las principales publicaciones donde aparecen textos del grupo, aunque sin definirlo en ningún momento: Diario de Melilla, El Telegrama del Rif, España en África, África española, España colonizadora, y Revista de Tropas Coloniales que luego se llamará África. Revista de Tropas Coloniales (pp. 17-20). El mismo autor definió algunas de las características de los africanistas, tales como el imperialismo y la retórica mortuoria, en su interesante aportación a un destacado libro colectivo sobre estos temas. Véase Moga Romero, Vicente: "La "cruzada del moro»: a contraimagen». En GonzÁlez Alcantud, José Antonio: Marroquíes en la guerra civil española. Campos equívocos. Anthropos Editorial, 2003, pp. 158-210.

51. Macías Fernández, Daniel: Franco «nació en África»..., pp. 348-349; Atienza Peñarrocha, Antonio: Africanistas y junteros..., p. 274; Iglesias Amorín, Alfonso: "La cultura africanista...", p. 106; GARCía Recio, María Ángeles: D'una guerra a una altra. Els militars africanistes espanyols: De Ben Tieb a Llano Amarillo (1924-1936). Tesis doctoral inédita, Universitat de les Illes Balears, 2015, pp. 154-155; Balfour, S. y La Porte, Pablo: "Spanish Military Cultures...», p. 315. 
Millán-Astray, Gonzalo Queipo de Llano o Francisco Franco. Estos famosos oficiales han servido de paradigma a la hora de definir al africanismo castrense, pero la extensión de su idiosincrasia a todo el grupo militar que se está estudiando puede resultar complicada. En cualquier caso, el liderazgo carismático de los mismos sentaría los puntos discursivos básicos del grupo que encabezaban. Por lo mismo, la mayor parte de los estudios que a continuación se señalan suelen estar basados, al menos de manera preferente, en este tipo de grandes líderes del movimiento africanista. No se puede determinar hasta qué punto este sesgo genera un estereotipo en sí mismo ${ }^{52}$.

Seguramente es la obra de Balfour la primera que se ocupa del fenómeno africanista desde una visión profesional de la historia ${ }^{53}$. Al mismo tiempo, salta de la historia militar tradicional a estudios que encajan más con la new military history y contienen cuestiones de tanto interés como la vida en la retaguardia o conceptos que se internan en las mentalidades de los cuerpos coloniales ${ }^{54}$. Su estudio Abrazo mortal: de la guerra colonial a la guerra civil en España y Marruecos no contiene una definición concreta del fenómeno africanista, pero ofrece caracterizaciones y un contexto cultural importante para entender al colectivo. Posteriormente han ido ampliando las nociones en torno a la cuestión en diferentes trabajos, algunos firmados junto a Pablo La Porte, acercándose al concepto a través de la idea de que se trata de una "cultura militar", entendiendo por tal un conglomerado de prácticas y mentalidades compartidas por un conjunto importante de oficiales ${ }^{55}$.

Más allá de las aportaciones de Balfour y La Porte, distintos autores señalan la vocación colonial, la voluntad de permanecer en el destino marroquí y/o, al menos, la permanencia prolongada en el escenario norteafricano, como una cuestión

52. Debe pensarse que el legado escrito de estos africanistas castrenses más icónicos (como sus artículos en la Revista de Tropas Coloniales) ha sido el más estudiado y quizá ello haya producido un sesgo a la hora de determinar los valores y objetivos de todo un grupo que, como se ha explicado, es muy complejo y sin una definición clara todavía. Además, al ser estos renombrados oficiales del arma de infantería y estar relacionados con unidades coloniales, se ha invisibilizado en la investigación a otros prestigiosos militares africanistas como Tomás García Figueras, artillero y reconocido erudito sobre temas marroquíes que ocupó, tras la contienda civil, diversos cargos como el de secretario general de la Alta Comisaría, delegado de Asuntos Indígenas, etc. Su perfil más arabista y su vinculación al arma de artillería no encajan a la perfección con el estereotipo previamente aludido. Seguramente este tipo de perfiles requieran más atención por parte de los investigadores. Véase al respecto su entrada en el Diccionario biográfico español de la Real Academia de la Historia, elaborada por Víctor Morales Lezcano, en donde es descrito como africanista. Consúltese también JENSEN, Geoffrey: «Muslim Soldiers in a Spanish Crusade: Tomás García Figueras, Mulay Ahmed er Raisuni, and the ideological context of Spain's Moroccan Soldiers». En: STORM, Eric y AL TumA, Ali: Colonial Soldiers in Europe, 1914-1945. "Aliens in Uniform" in Wartime Societies. Nueva York: Routledge, 2016, pp. 182-206.

53. BALfour, Sebastian: Abrazo mortal..

54. En torno a la definición de la new military history y su significado para el caso español, véase Gómez Ochoa, Fidel Ángel y Macías Fernández, Daniel: "De la historia militar a la historia bélica: el caso del combatiente». En Gómez OchoA, Fidel Ángel y Macías Fernández, Daniel: El combatiente a lo largo de la historia. Santander: PubliCan, 2012.

55. Balfour, Sebastian y La PORTE, Pablo: "Spanish Military Cultures...», pp. 311-13. 
definitoria de los oficiales africanistas ${ }^{56}$. Esto no significa que todos fuesen voluntarios a los campos magrebíes; la casuística puede ser diversa y, por ejemplo, algunos acabaron allí por las malas calificaciones en la Academia. En cualquier caso, lo importante no es el azar de la llegada sino la inserción en el escenario colonial y su identificación con un determinado grupo; es decir, la conformación de una cosmovisión africanista. Por lo tanto, es la permanencia en Marruecos, un destino de alto peligro en comparación con los peninsulares, lo que puede ser considerado un marcador grupal. En cualquier caso, la realidad es siempre más compleja y como dice el historiador Daniel Macías: "no todo el que estuvo en el norte de África fue un africanista ni fue percibido como tal por los integrantes de dicho sector». Si se comparte tal idea, sería un error incluir a cualquier oficial destinado en el Protectorado en el saco del africanismo ${ }^{57}$. De hecho, la historiografía refleja distinciones entre los destinados en la ribera sur del Mediterráneo, otorgando más complejidad a la sociología militar en la colonia: el artillero Antonio Cordón distinguía entre los militares africanistas y los "caponíferos", es decir, aquellos que estaban en Marruecos no por vocación sino para obtener mejores complementos salariales ${ }^{58}$. Significado similar debían tener los «emboscados", aquellos que trataban de esquivar a toda costa las operaciones y estaban vegetando en el territorio colonial. Estos solían ser relacionados con las Juntas de Defensa, aquellos que defendían los intereses de los que se solían calificar de "cobardes" 59 . Estos sindicalistas también estuvieron en la colonia, a pesar de las críticas de los africanistas y las fricciones que generaron entre familias militares. El historiador Eduardo González Calleja cita a los "palaciegos", los que pasaban parte de su carrera a la sombra de la Corte y solían obtener beneficios de ello ${ }^{60}$. Además de todos los tipos dichos, Balfour

56. Iglesias Amorín, Alfonso: "La cultura africanista...", p. 102, 106; Macías Fernández, Daniel: Franco..., p. 467-474; AtienZa Peñarrocha, Antonio: Africanistas y junteros..., p. 274.

57. Macías Fernández, Daniel: Franco..., pp. 39-40. El estudio de Ignacio Ezequiel García-Municio, por ejemplo, no realiza ninguna especificación y su lectura puede llevar a pensar precisamente en esta cuestión: a pensar que cualquier oficial en un destino prolongado marroquí, especialmente con mando sobre tropas coloniales, puede ser considerado africanista; pero, como se ha apuntado, la realidad de la oficialidad era más compleja. Véase Africanistas. Oficiales de tropas coloniales y del tercio en la Guerra de Marruecos. Barcelona: Avant editorial, 2019, pp. 18-19, 375; Enrique Gozalbes Cavrioto define de forma vaga a los africanistas de forma más o menos similar entendiendo que cualquier militar que participase en las operaciones en Jebala y el Rif puede ser considerado africanista, siendo Francisco Franco el ejemplo más granado entre estos militares. Gozalbes Cavrioto escribe sobre el africanismo franquista, lo cual pueda llevar al problema, del que se habla en este artículo, de definir el africanismo desde la perspectiva del franquismo y no tanto atendiendo a las características que pudo presentar en los años veinte, en plenas campañas militares: Gozalbes CAvrioto, Enrique: «El africanismo del primer franquismo: la revista África (1942-1956)». Miscelánea de estudios árabes y hebraicos. Sección Árabe-Islam, 64, 2015, p. 150.

58. Citado en Iglesias Amorín, Alfonso: "La cultura africanista...», p. 102 y ATIENZa PeÑarrocha, Antonio: Africanistas y junteros..., p. 455; Balfour y Pablo La Porte reconocen también la complejidad de la sociología existente en el Protectorado en «Spanish Military Cultures...», pp. 310-311, 314.

59. Macías FernáNDEZ, Daniel: Franco..., pp. 424-426.

60. Gonzélez CAlleja, Eduardo: El máuser y el sufragio. Orden público, subversión y violencia política en la crisis de la Restauración (1917-1931). Madrid: CSIC, 1999, p. 269. Macías hace referencia a 
y La Porte señalan otras culturas militares existentes en los campos de África: la "peninsular" y la "política». La primera se corresponde, atendiendo a su definición, a perfiles técnicos y sin vocación colonial, con poco entrenamiento, frecuentes durante el inicio de las campañas marroquíes entre 1909 y 1915. La segunda se refiere a militares que la II República (1931-1936) coloca en el Protectorado por simple cuestión de confianza política y, por lo tanto, se corresponden con un periodo avanzado de la conformación del africanismo ${ }^{61}$.

Además de la voluntad para servir en Marruecos, el africanista había de ser (preferentemente y siguiendo las explicaciones de Balfour y La Porte en lo que a "africanistas militaristas» se refiere) aquel oficial que sirve en cuerpos de fuerzas nativas como la Policía Indígena, los Regulares, las Mehal-las y las Harcas amigas o en cuerpos de choque como el Tercio de Extranjeros (cuerpo conocido como la Legión a partir de $1920^{62}$. En estas unidades, que solían situarse en vanguardia durante los combates para evitar bajas entre las fuerzas metropolitanas o en la extrema retaguardia durante los repliegues, es donde los africanistas castrenses labran sus rápidos ascensos. Por su parte, el Tercio es el cuerpo militar que se entiende como producto específico del pensamiento africanista: atribuida su fundación a Millán-Astray, recoge algunas de las ideas que se han esbozado para los africanistas y que se detallarán en las siguientes páginas ${ }^{63}$. Tal unidad mercenaria será uno de los instrumentos predilectos de castigo y represión para nativos insumisos ${ }^{64}$.

tal familia en el Protectorado y sitúa al general Fernández Silvestre entre sus filas. Ver MaCías FERNÁNDEZ, Daniel: Franco...

61. Balfour, Sebastian y La PORTE, Pablo: "Spanish Military Cultures...», pp. 323-326. Estos esbozos de identidades en el Protectorado y en la Península requieren de estudios más completos. A nuestro entender un tipo de identidad militar política podría ser la Unión Militar Antifascista y Republicana, véase para ello LosADA, Juan Carlos: El ogro identitario..., pp. 84-85.

62. Herrero Pérez, José Vicente: The Spanish Military..., p. 345; García-Municio, Ignacio Ezequiel: Africanistas. Oficiales de tropas...,p. 19.

63. El proyecto de fundación de un cuerpo de voluntarios extranjeros para combatir en las colonias del norte de África ya fue defendido por el general Agustín de Luque y Coca en 1916. Véase Luque, Agustín: Antecedentes para un proyecto de Ley Orgánica Militar que en su día ha de presentarse a Cortes. Madrid: Depósito de la Guerra, 1916. La cuestión es tratada en Puell De la VilLa, Fernando: "El Ejército de Tierra en tiempos de la Gran Guerra». Revista de Historia Militar, n. ${ }^{\circ}$ extra 1, 2019 , pp. 15-43. Un buen resumen en torno a la fundación del Tercio y su ideología en MaCías Fernández, Daniel: "Orígenes y fundación de la Legión (1920)». En VV. AA.: Cuadernos de Historia Militar 1. Cien años de la Legión, 1920-2020. Madrid: Desperta Ferro, 2020, pp. 11-12. La mejor obra sobre el Tercio es la del general Ballenilla, Miguel: La Legión española 1920-1927, la creación de una unidad colonial. Tesis doctoral inédita, Universidad de Almería, 2007. En esta obra se pueden apreciar las idas y venidas para la formación de una unidad mercenaria que ahorrase vidas españolas y en ella se defiende que la idea de la fundación del Tercio parte del Ministerio de la Guerra en 1919, encarnado en la figura de Antonio Tovar y Marcoleta, quien encargó a Millán Astray la labor de indagar en la unidad hermana gala.

64. Convendría recordar la cita que utiliza Alfonso Iglesias Amorín, tomada a su vez de una obra de Balfour, en la que el Alto Comisario Felipe Alfau se comunica con el ministro de Guerra Agustín de Luque, en el año 1912, y en la que se habla de proceder a la decapitación de los enemigos moros, pero con su conveniente ocultamiento a la opinión pública (Balfour cit. en Iglesias Amorín, Alfonso: "La cultura africanista...", p. 108). Esta cita es un buen ejemplo de cómo la brutalidad y las acciones 
Amén de la creación de unidades específicas para el combate en Marruecos, de los africanistas se ha destacado su conocimiento de tácticas novedosas de combate y su adaptación a los principios de la guerra colonial ${ }^{65}$. Sin embargo, esta afirmación debe ser considerada en una perspectiva histórica más amplia puesto que desde finales del siglo xix en el Ejército bullen distintos planteamientos acerca de la estrategia, la táctica y la organización militar. Algunas de las formas de combate más agresivas que entroncan en el modelo heroico de soldado y que se imputan al Tercio y a los africanistas pueden ya rastrearse en la literatura militar de finales del siglo XIX y fueron objeto de debate durante las Campañas de Marruecos, por lo que seguramente dentro de los africanistas también hubo distintos posicionamientos sobre la forma de conducir la guerra y puede que no todos aceptasen el modelo heroico de soldado ${ }^{66}$. De nuevo, muchas de estas características del africanismo castrense deben ser reconsideradas como una lenta evolución desde las guerras coloniales de Ultramar.

Otros estudios en la línea citada como cultural han ahondado en aspectos vinculados a los estudios de género, concretamente centrando la mirada en la construcción de una masculinidad que tiene mucho que ver con la identidad africanista. Gemma Torres es, probablemente, la historiadora que más ha profundizado en esta cuestión y señala que el ambiente cuartelario colonial fue un catalizador de la tendencia a la masculinidad en el contexto general de la milicia. Esta se forjaba a través de lo que se puede denominar la vida militar normal en colonias: había que demostrar arrojo, resistencia y temeridad en el campo de batalla frente al cálculo racional y la reflexión. A nivel general, la idea que subyace tras esta virilidad grupal es la ya citada del modelo heroico en el cursus honorum del africanismo. En cualquier caso, este ideal de masculinidad no sólo se circunscribía al campo de batalla, también a los entornos de sociabilidad que se veían afectados por lo mismo. Un caso significativo de lo dicho se daba en los burdeles: el hombre debía de "desfogarse» con mujeres para evitar la degeneración de la homosexualidad o las prácticas inaceptables como la masturbación. En el burdel la virilidad estaba vinculada al sometimiento de la mujer que, a su vez, encarnaba un estereotipo que tampoco encajaría con el ideal establecido para su género al ser un ejemplo de mujer "descarriada». En juegos y rituales de taberna también se reforzaban las conductas vinculadas a la masculinidad: las demostraciones de resistencia etílica eran claros duelos simbólicos para mostrar fortaleza. Este estereotipo masculino que configuraba parte de la cultura africanista parece ser un elemento de distinción de estas tropas que, curiosamente, llegó a dialogar con la masculinidad

\footnotetext{
bélicas sin cuartel y con amplio ensañamiento no son exclusivas del pensamiento africanista más tardío ni acciones únicas de militares legionarios.

65. Véase, por ejemplo, Amorín Iglesias, Alfonso: «La cultura africanista...», p. 103

66. Véase Herrero Pérez, José Vicente: The Spanish Military..., pp. 207-214
} 
-primitiva- atribuida al hombre rifeño, y que se yuxtapondrá al «hombre débil» de la metrópoli ${ }^{67}$.

Esta masculinidad en armas hizo que las virtudes marciales y viriles se llegasen a llevar al extremo de potenciar un cierto culto a la muerte y al sacrificio que, en realidad, es la potenciación del culto a la cicatriz ya mencionado. Esta mística en torno al combate y a la indiferencia por la herida y, en último caso, por la muerte, tiene su mejor plasmación en el Tercio de Extranjeros y todos sus rituales, símbolos y discursos asociados ${ }^{68}$.

Algunos de los más insignes africanistas, aquellos que hemos denominado líderes carismáticos del grupo, dejaron plasmadas sus opiniones en prensa y muchas de las mismas van en la línea de todo lo mencionado anteriormente. El vehículo preferente de propagación de ideas fue la Revista de Tropas Coloniales, también citada previamente, que se fundó en Ceuta en 1924 y que tenía la intención de generar un corpus doctrinal para la instrucción de los nuevos oficiales destinados a Marruecos, imitando la publicación francesa Revue des Troupes Coloniales fundada en $1902^{69}$. Tuvo colaboradores variados y trataba temas diversos: geografía, etnografía, historia, etc., pero también análisis militares y opiniones personales sobre los procesos político-militares en el Protectorado ${ }^{70}$. La revista fue, sin duda, un símbolo de poder mediático de cierto sector africanista castrense y cobró especial relevancia desde el final de la dictadura de Primo de Rivera. Hasta el fin de la guerra del Rif en 1927 fue un órgano de presión de los militares fundadores hacia la política colonial y la dirección del conflicto. Luego, al finalizar la contienda, los artículos de opinión dejarán de ser tan visibles y tendrán más espacio los escritos

67. Todo lo relacionado con la virilidad de los africanistas y su inserción como marcador de frontera grupal en: TorRes Delgado, Gemma: "El soldat espanyol i el guerrer rifeny: la construcció de la masculinitat a l'africanisme militar durant les guerres del Rif (1909-1927)». Segle xx. Revista catalana d'historia, 9, 2016, pp. 1-24; "La nación viril. Imágenes masculinas de España en el africanismo reaccionario después de la derrota de Annual (1921-1927)». Ayer, 106, 2017, pp. 133-158; MaCías FERnÁNDEZ, Daniel: Franco..., pp. 318-345.

68. Iglesias Amorín, Alfonso: La cultura africanista..., p. 105; Macías FernÁndez, Daniel: Franco..., pp. 352-367 y MACíAS FERNÁNDEZ, Daniel: «La crisis de la razón en la milicia colonial finisecular: la muerte como alternativa vitalista». En Necrofilia y Necrofobia, Valladolid: Cultura Iberoamericana, 31, 2009, pp. 263-278.

69. La publicación pasará por multitud de etapas y vicisitudes: primero tiene un paréntesis e irregularidad en su edición en el mismo año de su fundación para, desde 1925, aparecer mensualmente. Poco después, entre febrero del año 1926 y diciembre de 1928, pasó a llamarse África. Revista de Tropas Coloniales y entre enero de 1929 y junio de 1936 simplificó su nombre a África. Pasada la guerra civil tuvo un renacer en 1942 bajo el nombre de Revista Española de Colonización, aunque dos años después pasa a depender del Instituto de Estudios Políticos y a llamarse Revista de Acción Española. Finalmente se vinculará al Instituto de Estudios Africanos. Para mayor concreción véase Velasco De Castro, Rocío: "De periodistas improvisados a golpistas consumados: el ideario militar africanista de la Revista de Tropas Coloniales». El argonauta español [en línea], 10, 2013; Disponible en: https://journals.openedition. org/argonauta/1590; GozAlBes CAVRIOTO, Enrique: «El africanismo...», pp. 155-162.

70. García Recio, M. Ángeles: D’una guerra..., pp. 293-297; Velasco De Castro, Rocío: "De periodistas improvisados...", op. cit. 
de tipo antropológico y estudios históricos ${ }^{71}$. Por esto mismo, como demuestra la historiadora Irene González González al estudiar los números de la revista entre los años 1924 y 1936, el articulista con más cantidad de publicaciones en la revista es Gonzalo de Reparaz, geógrafo, y no un militar del sector africanista castrense ${ }^{72}$. Siguiendo a la islamóloga Rocío Velasco de Castro, la revista:

Constituyó uno de los principales medios de expresión del africanismo español de la época, de marcada tendencia marroquí, que propugnaba los éxitos de la labor civilizadora de España en el Norte de África y su papel de potencia colonial en virtud de sus lazos históricos y culturales con el mundo árabe ${ }^{73}$.

Este discurso colonial, en cierta forma heredero del africanismo decimonónico, si bien con un marcado carácter belicista como seña de identidad principal, ha sido entendido por algunos especialistas como continuador de la Liga Africanista Española (fundada en 1913) y de su revista África Española (publicada entre 1914 y 1917$)^{74}$. En ella participaron algunos ilustres militares de la familia africanista.

En cualquier caso, puede resultar atrevido aseverar que todo el complejo grupo militar del africanismo castrense comparta las mismas visiones colonialistas que el grupo fundador de Revista de Tropas Coloniales. Como ya se ha advertido, se requieren estudios que corroboren el influjo del ideario colonial de esta revista y de sus principales militares y articulistas en otros sectores de la milicia ${ }^{75}$. Se tiene que distinguir claramente entre el africanismo como discurso colonial, heredero de una tradición decimonónica, y el africanismo castrense como grupo militar, aunque ambas definiciones puedan converger en la publicación analizada en ciertos perfiles de oficiales. Esta diferencia no resulta del todo clara en ciertos trabajos $^{76}$.

71. Velasco De Castro, "De periodistas improvisados a...", en línea; Iglesias Amorín, Alfonso: "La cultura africanista...", p. 112; PARRA MONTSERRAT, David: La narrativa del africanismo franquista..., pp. 78-79.

72. GONZÁlEz GONZÁlEZ, Irene: "Las publicaciones africanistas españolas: el caso de África. Revista de Tropas Coloniales", Clio@Themis. Revue électronique d'bistoire du droit, 12, 2017, pp. 4-9.

73. Velasco De Castro, Rocío: «De periodistas improvisados a...», op. cit..

74. Parra Montserrat, David: La narrativa ..., p. 70, este autor junto con Rocío Velasco de Castro (véase, "La imagen del moro...») establecen las distintas fuentes de las que beberá posteriormente el discurso colonialista del franquismo (el denominado "africanismo franquista").

75. Hay que pensar que la revista se distribuía desde Ceuta a buena parte de la Península mediante suscripción, llegando también al extranjero y pudiéndose comprar en algunos quioscos de Madrid y Barcelona, así como estaciones de autobús y tren (GARcía Recio, María Ángeles: D’una guerra..., p. 90). Atendiendo a estos datos, la publicación vendería claramente su discurso colonialista a diferentes públicos y grupos sociales, por lo que excede el ámbito del africanismo castrense.

76. El texto ya citado de Alfonso Iglesias Amorín puede dar lugar a confusión al mezclar lo que es un pensamiento colonial (africanismo) con toda la idiosincrasia grupal militar (africanismo castrense). Desde luego un militar africanista podía aceptar el discurso colonial, pero un sujeto colonialista (africanista) no forma parte del colectivo militar que aquí se estudia. Son dos cuestiones distintas que, por lógica, en ocasiones pueden converger, como evidencian los propios fundadores de Revista de Tropas Coloniales, pero son a priori conceptos distintos que en algunas publicaciones parecen mezclarse. Así, David Parra Montserrat habla de "africanismo castrense» para referirse al discurso colonial más belicista 


\section{EL AFRICANISMO CASTRENSE: UNA PROPUESTA INTERPRETATIVA}

Durante las Campañas de Marruecos se forja un grupo militar denominado africanismo castrense. Como se ha visto anteriormente, no existe una definición unívoca o consensuada de lo que fue un militar africanista y los términos tienden a confundirse o a ser confusos y problemáticos en muchos casos. Además, existe un claro problema a la hora de definir las distintas culturas castrenses que florecieron entre la milicia del momento y, por supuesto, meter a los distintos militares en las distintas familias marcadas. Los estudios que de una u otra forma tocan el concepto de africanismo, y que se han ido citando a lo largo del presente artículo, se han dividido en dos vertientes: aquellos que hacen hincapié en aspectos como el intervencionismo castrense y/o la defensa del corporativismo militar, y los que se acercan a la cuestión africanista o la tocan dentro de publicaciones que se pueden entender como culturalistas. Ambas tendencias de investigación son complementarias y de una síntesis de las mismas pueden sacarse algunos puntos comunes que ayuden a conformar una definición: aunque el africanismo castrense no es uniforme y comparte espacio -físico y temporal- con otras facciones como los junteros, lo que puede llevar a desdibujar los límites de la familia militar, la historiografía ha consensuado que el africanismo se define, a nivel corporativo, por el ascenso en el escalafón militar por méritos de guerra y por defender una firme política de ocupación colonial en el Protectorado. Esta, tras la derrota de Annual (1921), llevó a los africanistas a posiciones maximalistas: la victoria había de basarse en aplastar al enemigo en el campo de batalla. Al mismo tiempo, una hipersensibilidad a las críticas, recuerdo del eco de 1898, los llevó al intervencionismo militar en la política metropolitana. El advenimiento de la dictadura de Primo de Rivera y la oposición a algunas políticas de la misma -y la presión consiguiente- fueron muestras de lo dicho en la década de los veinte. Ya en el periodo de la II República la tendencia se agudizó y tuvo su culmen en la participación masiva de los líderes insignes del africanismo en el golpe de Estado de 1936.

A un nivel más concreto, el militar africanista se distingue por ser oficial de tropas coloniales y tener una vocación de permanencia en la colonia que demuestra mediante un cierto interés en la cultura y/o lenguas de la zona, aunque sea de forma estereotipada, por ejemplo mostrándose al público con gustos orientalistas. En este contexto colonial, el africanismo castrense propugna y promueve una idea muy concreta de masculinidad, a saber: una muy vinculada a la guerra y que genera un ideal de soldado que había de caracterizarse por lo heroico, el cual se vinculaba al sacrificio. En la investigación, se suele insistir en este modelo castrense que prefiere lo irracional y lo efectista antes que lo efectivo y lo racional: el modelo técnico solía ser tachado de cobarde. El Tercio fue el cuerpo militar forjado con tales valores y se impregnó del espíritu de un

\footnotetext{
que puede leerse en la misma revista y, de la misma forma, puede provocar una confusión. Véase, IGLESIAS AMOrín, "La cultura africanista...”, pp. 110-111; PARRa MONTSERRAT, David: La narrativa..., pp. 69-85. 
africanismo maduro (contexto de la guerra del Rif y su pistoletazo de salida: el Desastre de Annual de 1921). Sin embargo, antes de llegar a ese momento, el grupo de los africanistas no fue homogéneo y, entre los estudios consultados, se ha dividido de varias formas: generacionalmente, por ideas políticas, en función de su tendencia al pacto con los indígenas, sus adscripciones operativas, etc. Ya se han señalado los problemas en torno a estas distinciones, y se requiere de mayores estudios para establecer delimitaciones más concretas y también se ha apuntado que algunas de las características atribuidas al grupo resultan matizables gracias a nuevas investigaciones.

Lo cierto es que la conformación de la cosmovisión africanista es fruto de un lento desarrollo y sus orígenes no han sido claramente estudiados. Hacer hincapié en todas las etapas y fases por las que se desarrollan en el contexto de las campañas de Marruecos, incluso retrotraerlas a las guerras de Ultramar, es importante para conseguir delimitar mejor a los africanistas y su evolución. De esta forma se puede romper una cierta tendencia observada en algunos estudios citados que definen o citan el africanismo entendiéndolo en retrospectiva o en base a sus principales figuras, es decir, a través de una serie de características extraídas de oficiales singulares y con trayectorias relevantes a partir de la última etapa de las campañas de Marruecos o los hechos históricos posteriores: el resplandor de la sublevación militar de 1936 y la posterior guerra civil.

Algunas de las líneas de investigación en las que se puede profundizar para tal fin pueden incluir el estudio de carácter biográfico; la realización de prosopografías que nos permitan entender la evolución de las trayectorias profesionales y políticas de la oficialidad destinada en el Protectorado; el estudio de rangos castrenses alternativos a los oficiales, jefes y generales, aquellos que se llevan la práctica totalidad de la atención, algo ya apuntado por Alfonso Iglesias Amorín 77 ; $\mathrm{y}$, de igual forma, resulta relevante la indagación sobre miembros de los técnicos para rastrear hasta qué punto la vinculación de los tácticos con el africanismo es mayoritaria. En el mismo sentido, puede resultar de enorme interés realizar un marco comparativo entre el ejército de colonias español y el de otros países europeos con similar tradición.

De esta forma, junto con el conocimiento cada vez mayor que tenemos de la presencia colonial en el Protectorado, podremos mejorar el difuso concepto de africanismo castrense y delimitar las diferentes ramas militares que pudieron operar dentro del mismo. Realizar esta tarea conllevaría, posiblemente, la deconstrucción de las categorías que hasta ahora se han propuesto para analizar el fenómeno y que, si bien hasta ahora han sido resolutivas en el análisis historiográfico, la evaluación en su conjunto que se ha realizado en este pequeño trabajo demuestra su inexactitud.

77. Iglesias Amorín, Alfonso: «La cultura africanista...», p. 110. 